\title{
On the Teaching Management Reform in College and Universities and Countermeasures under the New Situation
}

\author{
Sun Cui \\ School of Economy and Management \\ Shenyang Aerospace University \\ Shenyang City, China
}

\begin{abstract}
The purpose of Reform of modern education is to promote students' comprehensive development, then to improve their integrated ability. Nowadays, the reform of teaching management in colleges and universities has become focus issue of the whole society, and it requires relative educational department to do more research. In recent years, the scale of colleges and universities has been expanding, teaching theories has been updating, and teaching methods has been diversifying With the deepening of the reform, many new teaching forms and tasks have been applied to actual college and university management, which are more suitable for routine teaching management of colleges and universities. But as for the present teaching management of colleges and universities, there exist more or less problems, most of the leader's ideas are sorts of conservative, and the leaders pay not enough attention to teaching management, so the managerial personnel lax in their work and lack of creative ideas. What worse, the inner managerial system in colleges and universities is not yet perfect, professional education management talents are needed. Considering the specific characteristics of College teaching management, educational reform on this aspect has been considered as the urgent task that need to be undertaken. This paper analysis the problems existing in college and university teaching management and proposes relative reform paths, then summarizes the the significance of the teaching management reform.
\end{abstract}

Keywords- Higher education; Teaching management;

Reform measures; Countermeasures analysis

After joining the WTO, China's economic developed rapidly, coupled with the new situation of education reform policies and other factors, the education industry has ushered the spring of development. So, our country's institutions of higher education should consider how to reform in order to adapt to the current teaching management. In addition to the strict management, to strengthen the reform of teaching management is necessary. Through the reform of teaching management, it can improve the management system and improve the teaching quality, which is also an important way to cultivate talents. Strengthen the teaching management work is to strengthen the control of the entire university management, making the daily work more tend to scientific and reasonable. However, the data show that our country's university teaching management work should be improved and there is a certain way to go, which have different problems in different levels. It affects the sustainable development of colleges and universities from the micro aspect, and affects the reform process of modern education reform from the macro aspect. So, it is the most important problem for the colleges and universities to find out and improve the problem in the reform of the teaching management through specific examples, and it is also a problem worth thinking for all educators.

\section{SCIENTIFIC CONNOTATION OF TEACHING MANAGEMENT REFORM IN COLLEGES AND UNIVERSITIES}

\section{A. To Improve the Competitiveness of Colleges and Universities}

From the perspective of literal, the reform of teaching management in Colleges and universities is to achieve the ultimate goal of teaching management through internal management activities. However, this general statement is not a kind of definition, and its real conation is to build a kind of organization form and responsibility distribution system through reform or innovation in the activities of teaching management in the face of domestic and international competition. In our country, the reform of teaching management in Colleges and universities is discussed long time ago, and the purpose is to enhance the competitiveness of the University and to cultivate outstanding talents for the country. The teaching management in Colleges and universities is an important part of the modern education reform, it should be combined with the current college teaching management idea and ensure that it is real and effective in the construction process, rather than letting it be superficial.

B. The Reform of Teaching Management is the Inevitable Choice for the Development of Colleges and Universities

The reform of teaching management in Colleges and Universities is advocated by our country, which is in line 
with the requirements of the modern education reform, and also with the development trend of the current era. In recent years, the teaching mode of higher education in our country has been changed. With the number of students increasing, the higher education has been transformed into mass education. Therefore, the reform of teaching management at this stage is the inevitable choice for the development of colleges and universities. We can find suitable teaching management methods for the development of colleges and universities through the traditional teaching mode of innovation, and then making the management of resources to achieve the optimal allocation.

\section{It Can Improve the Teaching Quality of Colleges and Universities}

In recent years, with our country paying close attention to and the increasing education funding for higher education, education management mode in colleges and universities has been accepted by most of the enterprises in society, and the number of university graduates also has increased gradually in the society with the time changes. However, from the social feedback, the situation is not optimistic. Most graduates have weak practice ability and even lack the basic work ability; and the comprehensive quality of some students is not high, having no sense of responsibility and considering their own interests only. The purpose of education in Colleges and universities is to put talents into society. So it is the most thing to deepen the teaching management reform and improve the management system, it is also an effective way to improve the teaching quality.

\section{PROBLEMS IN THE CURRENT UNIVERSITY}

\section{TEACHING MANAGEMENT REFORM}

With the continuous implementation of the university education reform, the role of teaching management is more prominent, which can ensure the orderly conduct of the work of the University. It played a great role in the internal management and has gradually become the standard of evaluation of University management. However, some of the problems exposed in the reform process have to let us pay attention to:

\section{A. personnel responsible for teaching management are not pay attention to work}

The current teaching management system is not perfect, many people especially the leadership of some colleges and universities know a little about the theory. Standardized teaching system cannot be built up, and it is common to deal things according to experience in the process of teaching management and there are inevitably omissions, which is unsystematic. Another more prominent problem is that people do not follow the rules, which means that the teaching management works only be on the surface. It only works when the leadership examines for the sake of appearance and cannot make any difference. In addition to the leadership, the understanding of many staff responsible for teaching management is not complete, only dabbled in the literal meaning and will become a mere formality in the wake of the teaching management work; or the staff was not serious and has been lax in the work, thus will lead to university's teaching management level being weak and do damage to the continuous development of colleges and universities.

\section{B. The Imperfection of Teaching Management System}

Because of the neglect of teaching management in some colleges and universities or because of the environment, capital and human resources, the establishment of teaching management is hindered; it is also weak even after the establishment of teaching management system. So the teaching management work will only be superficial under this situation, and its scientific rationality is very difficult to guarantee. And the teaching management concept of university staff is relatively backward, still remaining at the administrative management in the past and not to adjust the structure of the internal staff timely. In addition, it still limits the behavior of the whole school teachers and students with traditional teaching management mode, which is not people-oriented. This is not only against the enthusiasm of the whole school teachers and students to learn, but also is not conducive to the deepening reform of college teaching management.

\section{The Supervision of Teaching Management is not enough}

The teaching management work is closely related to monitoring efforts, if the former is inadequate, it will lead to weak monitoring system, makes a lot of behavior which are not according to the standardization of the teaching management and lead to the teaching management system become a mere scrap of paper. The reason for this is because the internal managers have conflicting psychology towards the teaching management system and cannot cooperate actively. And some colleges and universities attach importance to development but underestimate management, sniffed the monitoring system of teaching management, which led to some teachers' behavior is not constrained, and it is prone to have management issues. What's more, the responsibility system is not implemented, the manager does not have a sense of participation of the teaching management, and it is also difficult to implement the problem to the responsible person. The most serious is that the teaching quality evaluation system is not perfect, many colleges and universities usually adopt "one class" standards in the assessment process, this is not scientific, because the teacher may get good evaluation results if he prepares fully. In general, it is the teaching management system that limits the workers' rights, resulting in the construction of teaching management system being facial.

\section{The Arrangement of the Teaching Task in Colleges and Universities is Unreasonable}

In our country, the teaching organization and management mode of the colleges and universities adopts the hierarchical system, and only the leader has the decision-making power. And the development of the contemporary era is based on economic interests, the pressure from the social aspects also block the establishment of the university teaching management 
system. In order to make the rapid development of this school, the management of the university usually adopts the method of reducing the cost and saving the teachers, which can cause many courses unable to be completed. There are some universities pay attention to skills training and neglect the management personnel training, only to strengthen the construction of teachers and the training of professional skills. The school thinks that the practical talents are the foundation of national survival and development, but the management talents are only playing with mouth and pen. And most of the courses offered by the school are out of date, but teachers are forced to talk about the teaching task of the school, which can not only make students lose interest in learning, but also affect the teaching progress.

\section{E. The Quality of Teaching Management Staff is Poor}

Teaching management staff of the colleges and universities are not only to ensure the smooth development of the teaching work, but also responsible for the daily management of the university's internal activities. But at present, the comprehensive quality of teaching management staff of university is poor, having no belief or the consciousness of faith is weak, and the ability to resolve the affairs also exist a lot of difference. In the daily teaching management work, the staff is not to be interested in gaining merit, but only in avoiding making mistakes. All in all, in the process of teaching management, management personnel lack of innovation spirit and enthusiasm. And the professional quality of some manager goes up, but the quality of character is not high enough, if they find some management loopholes, they will not only report them but also take advantage of these loopholes to corrupt. Therefore, it is urgent to improve the comprehensive quality of teaching management staff.

\section{ANALYSIS ON THE COUNTERMEASURES OF THE}

\section{TEACHING MANAGEMENT IN COLLEGES AND}

\section{UNIVERSITIES UNDER THE NEW SITUATION}

\section{A. To enhance the sense of responsibility of managers}

It only can carry on the teaching management work and make the University's teaching management more thoroughly implemented if we improve the responsibility consciousness of college teaching management staff and the responsible person. First, managers should fully understand the importance of teaching management work for the sustainable development of colleges and universities, and learn related teaching management ideas; second, the managers should develop teaching management system according to the University's internal realities and improve itself during the continuous development process; finally, it is essential to provide staff with regular publicity and education about teaching management, so it will form a working atmosphere to implement of specific work responsibilities.

\section{B. To Improve the Teaching Management System}

Teaching management system includes management system, personnel arrangement and management report analysis, and the establishment and perfecting needs the internal interaction and complement within the Colleges and Universities. The teaching management tasks and duty division made under this premise will make all management information feed back as fast as possible. University administrators should update the original teaching management mode and serve the whole school teachers and students with all efforts. In the teaching management work, we should implement the people-oriented concept, cultivate and improve the students' comprehensive quality as far as possible, and strengthen the construction of campus culture, so as to promote the vigorous development of colleges and Universities.

\section{To Strengthen the Supervision of Teaching Management}

Colleges and universities should develop a suitable and perfect evaluation system, in which all work be regulated. From specific aspects, we can strengthen internal and external audit to further standardize the behavior of all teachers. Above this specification, it can establish a supervision system to check whether the teachers have taught according to the school arrangement, and if there is behavior illegal or do damage to the interests of the school among the management personnel, such as corruption, embezzlement, etc. Besides, we should establish an appropriate reward and punishment system, rewarding outstanding management personnel and teachers, which can greatly stimulate their enthusiasm; punishing the teachers who violate the regulations to avoid repeating them. This will ensure the stability of the internal teaching management in colleges and universities, and to achieve the goal of teaching management.

\section{Teaching Task Arrangement Rationalization}

With the reform of college teaching management, it must make the arrangement of teaching task reasonable if the school want stable development. First of all, the management levels need to realize the importance of teaching quality for students and even for school. We cannot delay the student's promising future just in order to save the cost of teaching. Secondly, the teaching management staff should go into the school to investigate to understand the classroom state of teacher and students. To arrange some excellent teachers for students to teach professional courses, and actively guide students to carry out diversified development. In addition, the teachers can also express their most real attitude towards the teaching task arranged by school through the form of research, which is more conducive to the smooth progress of teaching management.

\section{E. To Improve the Quality of Teaching Management Staff}

In view of the low quality of teaching management staff in Colleges and universities, the following measures are put forward. First of all, we should strengthen the professional quality of the teaching management staff, and study the problems in the work, 
so that it can grasp the relevant work procedure and level, so that the error can be reduced to a minimum. Next is the education of professional ethics, it should comply with the school system and the state law to prevent the occurrence of corruption. Finally, the university can separate the unrelated duties according to their own situation in order to make the education management work tend to be fair and equitable.

\section{CONCLUSION}

Under the double situation of international situation and domestic education reform, the reform of teaching management in Colleges and universities is extremely urgent. We must finish our duty work earnestly according to the internal problems of its own, change the original concept of teaching management, establish the excellent teaching management system correspondingly, and thus fundamentally improve the management level of colleges and universities. And it can ensure the stable development of colleges and universities, and to promote the vigorous development of national education on this account.

\section{REFERENCES}

[1] GU Zili. On the Teaching Management Reform in College and Universities and Countermeasures under the New Situation.[J]. Teaching and Learning Forum, 2011 (10).

[2] LI Zhongmin, ZHANG Hong. My View on Teaching
Management in Colleges and Universities.[J]. Experimental Science and Technology, 2004 (4).

[3] ZHENG Wenfa. The Impact of Higher Education Informatization on the Reform of Teaching Management.[J]. Journal of Jimei University, 2003, (4): 88-91.

[4] PAN Weizhen. Functions, Organization and Methods: the Role Transition of the Teaching Management in Colleges and Universities [J]. Jiangsu Higher Education, 2008, (3): 67-69.

[5] LI Lin. Thinking Change of the Teaching Management in Colleges and Universities [J].Hunan Tides (the second half), 2010, (3): 64-65

[6] HUANG Xiaolin. On the Construction of the Educational Environment of College Dormitories.[J]. Journal of Xingtai Polytechnic College, 2004, (12) 52-53.

[7] QI Zhongfeng. On the Teaching Management Reform of Higher Education under the New Situation.[J]. Petroleum Education, 2006, (5): 60-61.

[8] XUE Rong. Research on Teaching Management in Colleges and Universities Based on Customer-centered Theory.[J]. Journal of Zhejiang University of Technology (SOCIAL SCIENCE EDITION), 2008, (4): 426-431.

[9] SONG Hongfeng, XU Peng. Using the Concept of Enterprise to Promote the Teaching Management Reform in the Colleges and Universities.[J]. China Geological Education, 2006, (4): 68-70.

[10]The Points of Teaching Management in Higher School.(Teach High Division (1998) 33).

[11] Assessment of the level of Undergraduate Teaching in Guangdong University of Foreign Studies (2003).

[12] LIU Jinjian. A Special Report on the Connotation of The Points of Teaching Management in Higher School. http://pg. cqnu. edu. $\mathrm{cn} /$ show news. asn?newsid=725. 